\title{
Molecular cloning and comparative sequence analysis of fungal $\beta$-Xylosidases
}

\author{
Ghulam Mustafa', Sumaira Kousar ${ }^{1,2}$, Muhammad Ibrahim Rajoka ${ }^{3}$ and Amer Jamil ${ }^{1 *}$
}

\begin{abstract}
Commercial scale degradation of hemicelluloses into easily accessible sugar residues is practically crucial in industrial as well as biochemical processes. Xylanolytic enzymes have a great number of possible applications in many biotechnological processes and therefore, these enzymes are continuously attracting the attention of scientists. Due to this fact, different $\beta$-Xylosidases have been isolated, purified and characterized from several bacteria and fungi. Microorganisms in this respect have gained much momentum for production of these significant biocatalysts with remarkable features. It is difficult to propagate microorganisms for efficient and cost-competitive production of $\beta$-Xylosidase from hemicelluloses due to expensive conditions of fermentation. The screening of new organisms with an enhanced production of $\beta$-Xylosidases has been made possible with the help of recombinant DNA technology. $\beta$-Xylosidase genes haven been cloned and expressed on large scale in both homologous and heterologous hosts with the advent of genetic engineering. Therefore, we have reviewed the literature regarding cloning of $\beta$-Xylosidase genes into various hosts for their heterologous production along with sequence similarities among different $\beta$-Xylosidases. The study provides insight into the current status of cloning, expression and sequence analysis of $\beta$-Xylosidases for industrial applications.
\end{abstract}

Keywords: Hemicellulose, Exoglycosidase, Xylanolytic enzymes, $\beta$-Xylosidase, $\beta$-Xylosidase cloning, $\beta$-Xylosidase expression

\section{Introduction}

Microorganisms are the natural producers of enzymes due to their abundance in nature and are thus central to biomass conversion. Biomass consists of cellulose as a primary component while hemicellulose being the second most abundant constituent of plant cell wall comprises a heterogeneous molecule named xylan (Ahmed et al. 2012). Microorganisms efficiently hydrolyse xylan into monosaccharides through the action of a battery of enzymes to obtain higher yields for industrial applications. Complete degradation of xylan backbone into its monomers by microbial world is a multistep process which requires concerted action of hemicellulases and cellulases based cocktail. Xylanases and $\beta$-Xylosidases are

\footnotetext{
*Correspondence: amerjamil@yahoo.com

1 Department of Biochemistry, University of Agriculture, Faisalabad 38040, Pakistan

Full list of author information is available at the end of the article
}

among the major enzymes of this cocktail (Menon et al. 2010).

$\beta$-Xylosidase (EC 3.2.1.37) is an exoglycosidase having ability to hydrolyse the non-reducing ends of xylooligosaccharides into xylose (Saleem et al. 2012) (Fig. 1). It is widely disseminated in nature and is one of the component enzymes of hemicellulose complex (Rajoka 2007). For large scale production of $\beta$-Xylosidase, microbial cultivation is very unwieldy and it often ends up in many interfering enzymes as a pure form of a particular enzyme becomes difficult to be isolated from a microbial preparation. Therefore, efficient and cost effective hydrolysis of biomass is generally preferred and alternative sources are being searched (Kanna et al. 2011). In this respect fungi and bacteria play a central role in the degradation of complex plant polymers. This hydrolysis is accomplished by the xylan hydrolyzing enzymes produced with novel and desirable characteristics (Banerjee et al. 2010). Filamentous fungi and mesophilic and thermophilic bacteria are considered to be the attractive 


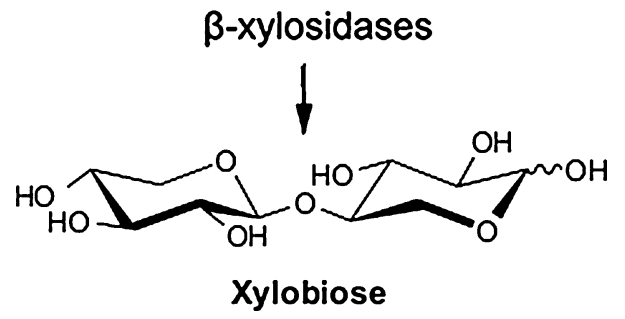

Fig. 1 Schematic representation of hemicellulose degradation by $\beta$-Xylosidases which release xylose from xylobiose (Kousar et al. 2013)

source of $\beta$-Xylosidase (Lorenz and Wiegel 1997). However, productivity and stability varies among different microbial species with respect to practical applications. Therefore, natural sources for the enzyme with increased thermostability, greater specific activity, efficient ability of translation and more resistance to proteases are of considerable interest for industrial applications.

Before recombinant DNA technology the industrially important enzymes were produced from microorganisms. Genetic engineering has been proved to be an alternative to the extreme and expensive conditions of fermentation. In spite of the availability of biochemical and molecular information about $\beta$-Xylosidase a very little progress at the genetic level has been reported. A detailed evaluation of the biochemical characterization and regulation of the enzyme at molecular level requires genetic analysis of the gene encoding $\beta$-Xylosidase (Girio et al. 2010). In our previous work we discussed a detailed study of biochemical characterization of $\beta$-Xylosidase from bacterial and fungal sources (Kousar et al. 2013) whereas here we report gene manipulation of the enzyme and its expression in different hosts.

\section{Cloning of fungal $\beta$-Xylosidase genes}

Fungi have been used for more than 50 years for the production of industrially important enzymes and microbial biomass proteins (Mustafa and Jamil 2013). From a pool of fungal proteins, the isolation of required enzymes requires not only monotonous steps but also increases their costs (Montibeller et al. 2014). For this purpose, recombinant DNA technology is used with more success as these enzymes can be expressed in both homologous and heterologous protein expression hosts on a large scale (Korona et al. 2006). For enhanced production of industrially important enzymes by improved substrate utilization and other useful properties on commercial scale, many genes have been cloned and expressed (Ahmed et al. 2009). The selection of xylanolytic enzymes having industrial applications is a result of recombinant DNA technology (Kvesitadze et al. 2014).
From Aspergillus niger a $1.9 \mathrm{~kb}$ DNA fragment containing $\beta$-Xylosidase gene $(x \ln D)$ was generated and used as a specific probe (Perez-Gonzalez et al. 1998). A complete $\beta$-Xylosidase gene $(x l o A)$ was isolated from Vibrio sp. strain XY-214 genomic DNA with the help of AlkPhoslabeled probe that gave $4.2 \mathrm{kbp}$ fragment of $x$ loA (Umemoto et al. 2008). The coding region of $\beta$-Xylosidase $(x \ln D)$ gene from $A$. niger yielded a mature protein of $85.3 \mathrm{kDa}$ (Perez-Gonzalez et al. 1998) that resembles closely to the $\beta$-Xylosidase previously isolated from $A$. nidulans having a molecular mass of $85 \mathrm{kDa}$ (Kumar and Ramon 1996). The activity and thermostability of $\beta$-Xylosidase and xylanase from A. ochraceus have been improved by mutagenesis through UV and NTG (Biswas et al. 1990).

\section{Cloning in Fusarium sp}

So far most of the studies on genetic manipulation of Fusarium sp. have been carried out related to phytopathological action of Fusarium oxysporum. First homologous transformation system of this fungus was developed by (Diolez et al. 1993) that was based on cloning of nia gene encoding NR from F. oxysporum. Gene replacement events, integrations at non-homologous sites and single-copy homologous integrations were observed, and transformation frequencies were achieved up to 6000 transformants per $\mu \mathrm{g}$ of DNA. The transformation system in $F$. oxysporum was offered by new applications of gene replacement events which were observed at high frequency (in $50 \%$ of the transformants). GareiaPedrajas and Roncero (1996) reported a highly efficient transformation system in $F$. oxysporum including DNA transformation of protoplasts mediated by PEG and protoplasting based on a mutant of NR which was complementary to homologous nitl gene and on the autonomously replicating sequence (ARS) and telomeric sequences presence in the vector. The applications of Agrobacterium tumefaciens-mediated transformation (ATMT) to F. oxysporum were described by Mullins et al. (2001) through novel binary vectors constructions, selection of ATMT conditions that affect the efficiency of transformation, inserted T-DNA copy number in $F$. oxysporum and bringing hygromycin $\mathrm{B}$ phosphotransferase gene $(h p h)$ from bacteria under A. nidulans promoter $(\operatorname{trpC})$ as a selectable marker.

A gene replacement method in $F$. oxysporum was reported by Khang et al. (2005) based on ATMT with a mutant allele of targeted gene and as a marker of conditional negative selection against ectopic transformants. The gene was flanked by HSVtk gene having the function to convert 5-fluoro- $2^{\prime}$-deoxyuridine into a compound that is toxic to various fungi. The mutants of gene 
replacement lack HSVtk while it is expressed by ectopic transformants. Through counter-selection against ectopic transformants identification of targeted mutants is facilitated by growing transformants on a medium supplemented with 5-fluoro-2'-deoxyuridine. Following the treatments with UV or NTG the activity of $\beta$-Xylosidase and xylanase enzymes was enhanced by more than threefold through mutagenesis of $F$. oxysporum DSM 841 (Singh et al. 1995).

\section{Cloning in Escherichia coli}

Escherichia coli is an ideal platform for the expression of recombinant proteins (Tables 1,2 ). There are heterologous proteins such as xylanases which cannot be expressed in this host functionally due to repetitive appearance of rare codons in addition to disulfide bond formation (Stewart et al. 1998) and glycosylation like requirements for specific post translational modifications. E. coli can perform simple O-glycosylation only but xylanases require N-glycosylation (Messner 2009). Exceptionally, from a thermophilic fungus $P$. thermophila a glycosylated $\beta$-Xylosidase gene was functionally expressed in E. coli (Teng et al. 2011). The extracellular expression of this gene has indicated that glycosylation was not essential for its activity. From Klebsiella oxytoca a xylo-oligosaccharide (XOS) utilization operon encoding a xylosidase and xylobiose/cation symporter was expressed in E. coli KO11. This expression resulted in successful consumption of XOS having xylosyl up to six residues (Qian et al. 2003). Therefore, multiple factors including rapid growth on inexpensive media, simple practices of transformation and easy isolation and purification techniques have made $E$. coli a successful candidate of recombinant expression platform.

\section{Expression of $\beta$-Xylosidase genes Expression in Escherichia coli}

Escherichia coli has been extensively used as a host microorganism for the production of recombinant proteins because of many expression advantages including simplified downstream processing, increased biological activity, enhanced product stability and solubility and authenticity of N-terminus of expressed proteins (Mergulhao et al. 2005). Considerable attention has been given to extracellular production of recombinant enzymes in $E$. coli as it has substantial advantages over periplasmic or cytoplasmic productions (Sommer et al. 2010). For heterologous gene expression in $E$. coli a number of different expression vectors and host strains are used. Liang et al. (2009) cloned Bxyl gene from Bacillus halodurans $\mathrm{C}-125$ with its own promoter and transcription terminator into $\mathrm{pQE80L}$ expression vector and transformed into $E$. coli JM109. Using $p$-nitrophenyl- $\beta$-Xylose
(pNPX) as a substrate the crude enzyme was analyzed for its xylosidase activity which was estimated to be 11 $\mathrm{U}$ from $450 \mathrm{~mL}$ cultivated cells of $E$. coli. The open reading frame of another $\beta$-Xylosidase gene $(x y s B)$ along with its promoter region was isolated from Aeromonas caviae ME-1 and cloned into pT7-Blue vector to express in $E$. coli DH5 $\alpha$ (Suzuki et al. 2001). The specific activity of the enzyme XysB was finally enhanced to $56 \mathrm{nKat} / \mathrm{mg}$ protein.

For the expression of recombinant proteins in E. coli the $\mathrm{pET}$ expression vector systems are categorized among the most effective ones. Tsujibo et al. (2001) used an expression vector pET-20b(+) to overexpress a $\beta$-Xylosidase gene $(b x l A)$ with no typical -10 and -35 promoter boxes from Streptomyces thermoviolaceus in $E$. coli BL21 (DE3) pLysE. The enzyme BxlA was produced in the cytoplasm induced by IPTG and from a $1.2 \mathrm{~L}$ culture of $E$. coli $50 \mathrm{mg}$ of purified enzyme was obtained. A fungal $\beta$-Xylosidase gene $x y l B$ from $A$. oryzae was cloned into $\mathrm{NcoI} / \mathrm{XhoI}$ site of vector $\mathrm{pET} 32 \mathrm{~b}$ and transformed in E. coli Rosetta-gami ${ }^{\mathrm{TM}}$ (DE3) pLysS. The enzyme was expressed with three tags i.e. $\mathrm{N}$-terminal thioredoxin tag, His-tag and S-tag (Suzuki et al. 2010). Another $\beta$-Xylosidase gene TlXyl43 from Thermomyces lanuginosus was amplified and cloned into the NheI/SacI site of pET28a(+) vector and expressed in E. coli BL21 (DE3) (Chen et al. 2012a). Twenty-three amino acids encoded by the vector were added at the $N$-terminal of wild-type enzyme but no potential secretion signal peptides were predicted in wild-type or recombinant TlXyl43 enzyme. However, secretory expression was predicted in both wild-type and recombinant enzymes and this type of secretion should be attributed to non-classical secretion of the enzyme.

\section{Expression in fungi}

Bacterial enzymes are mostly expressed heterologously in E. coli (Teng et al. 2011) but fungal enzymes are generally purified from their original cultures (Ohta et al. 2010) or produced in different high-level expression systems such as Aspergillus (Kitamoto et al. 1999) or P. pastoris (Chen et al. 2012b). With methanol induction a $\beta$-Xylosidase (Xyl3A) from Humicola insolens Y1 was successfully overexpressed in P. pastoris GS115 without signal peptide (Xia et al. 2015) and the secretion of enzyme was facilitated by using the signal peptide of the yeast $\alpha$-factor into the culture supernatant. The yield of Xyl3A was found approximately $100 \mathrm{mg} / \mathrm{L}$ which suggested that it had great potential for cost effective production on a large scale. A considerable stability was found in $\beta$-Xylosidase isolated from Paecilomyces thermophile and expressed in Pichia pastoris. After $72 \mathrm{~h}$ of incubation the enzyme was found with maintained activity at optimal temperature of 


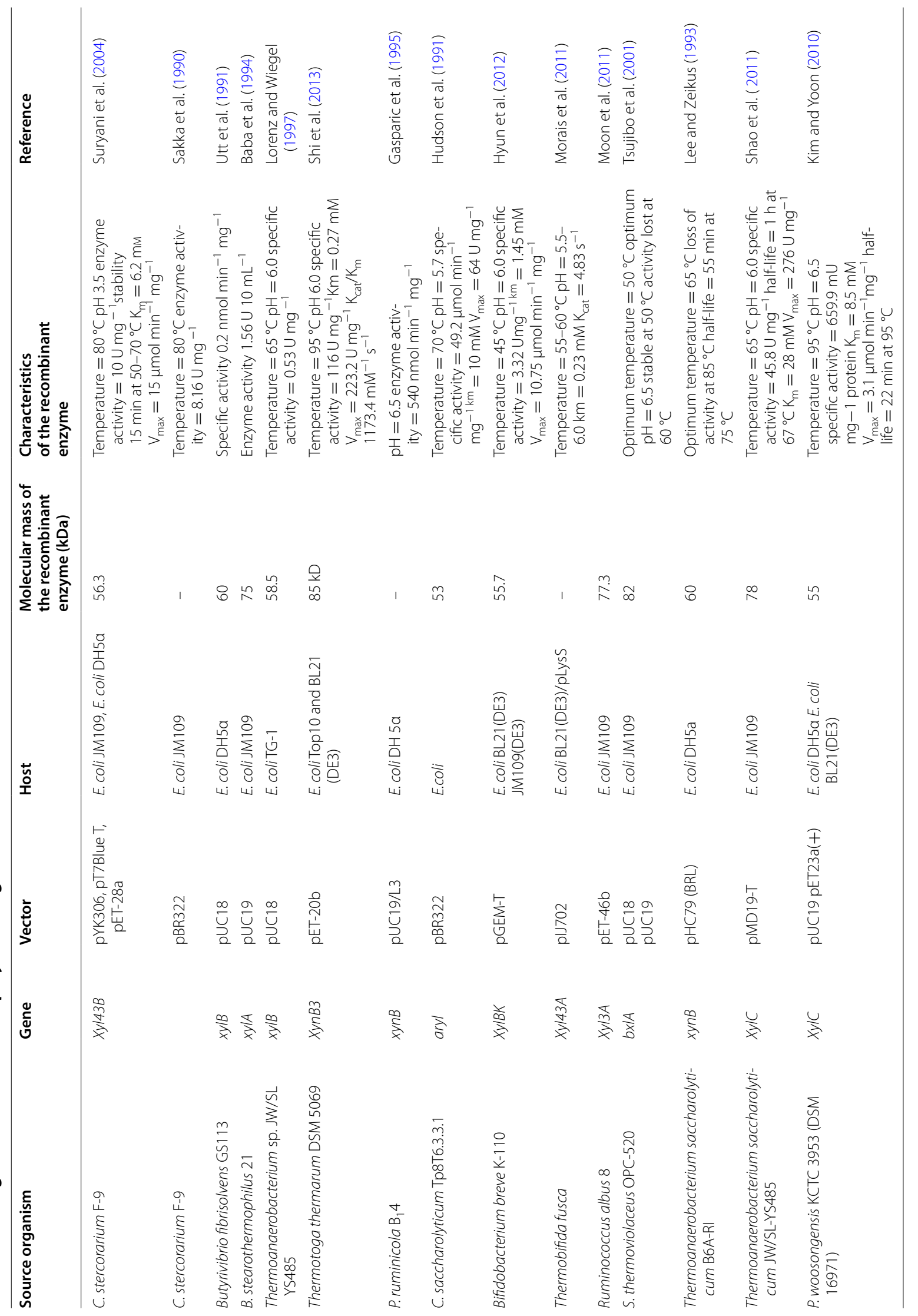




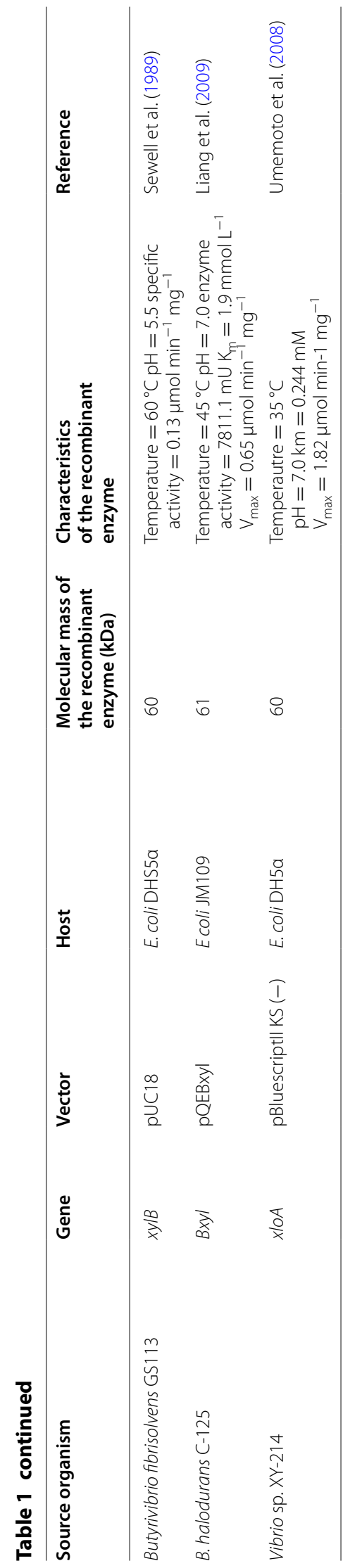




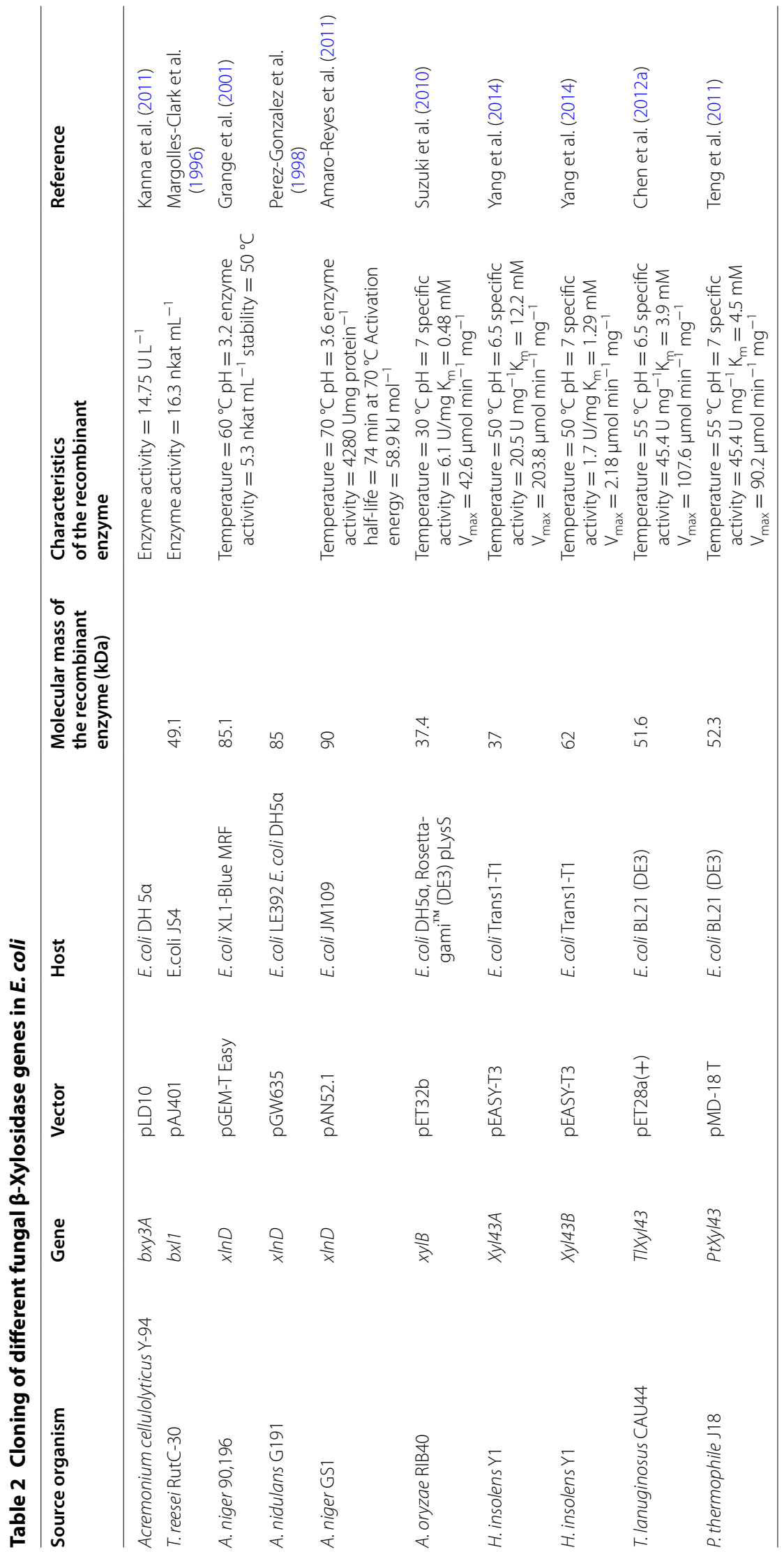


$60{ }^{\circ} \mathrm{C}$ and the molecular weight of enzyme was calculated to be $52.3 \mathrm{kDa}$ which was found to be active at pH 7 (Juturu and Wu 2013). Another $\beta$-Xylosidase gene i.e. Tlxyn1 was isolated from T. lanuginosus SSBP and cloned and expressed in P. pastoris GS115. A GAP promoter system executed the expression of recombinant $\beta$-Xylosidase. The coding region of Tlxyn 1 was not interrupted by any introns similar to some other $\beta$-Xylosidase genes observed from filamentous fungi (Gramany et al. 2015).

\section{$\beta$-Xylosidase expression system of filamentous fungi}

In industry, enzyme production by fermentation using fungal expression systems has a long history. For T. reesei a number of genetic tools have been developed such as different transformation strategies like protoplast based transformation (Gruber et al. 1990), biolistic transformation (Te'o et al. 2002) and ARS (Zhong et al. 2006) and were shown to be successful. There are different selected markers like benomyl (Peterbauer et al. 1992; Schuster et al. 2007) and hygromycin (Mach et al. 1994) resistant, the auxotrophic markers like $h x k l$ (Guangtao et al. 2010) and pyr4 (Gruber et al. 1990), and amdS gene from $A$. nidulans that confers the ability to grow on acetamide as a sole source of nitrogen (Penttila et al. 1987).

Moreover, a sexual cycle in $T$. reesei (Guangtao et al. 2009) has been discovered which has further increased the industrial potential of the fungus. It was further reported that $T$. reesei could survive up to 13 days under anaerobic conditions. All these observations are in accordance with the fact that in $T$. reesei genome all genes are required for conversion of cellulosic sugars into ethanol (http://genome.jgipsf.org/Trire2/Trire2.home. html). For $\beta$-Xylosidases production, Penicillia have been described to be good producers (Curotto et al. 1994). Two $\beta$-Xylosidases produced from the cell surface of $P$. herquei were identified and purified (Ito et al. 2003). Different carbon sources can be used to induce and express $\beta$-Xylosidases from Penicillia (Krogh et al. 2004). The production of $\beta$-Xylosidases has been explored in a number of Penicillia species including P. brasilianum (Thygesen et al. 2003), P. chermisinum (Reese et al. 1973), $P$. funiculosum (Krogh et al. 2004), P. herquei (Ito et al. 2003), P. islandicum (Reese et al. 1973), P. janthinellum (Curotto et al. 1994), P. persicinum (Krogh et al. 2004), $P$. pusillum (Reese et al. 1973), P. roseopurpureum (Reese et al. 1973), Penicillium sp. AHT-1 (Rahman et al. 2003) and P. wortmanni (Reese et al. 1973). The best carbon source was found to be xylan in all these Penicillium species except $P$. brasilianum that was grown best on wetoxidized wheat straw (Thygesen et al. 2003).

\section{$\beta$-Xylosidase expression system of yeasts}

For the expression of heterologous proteins, yeasts are a good choice and preferred over bacterial expression systems (Table 3 ). The ability to accomplish post-translational modifications in eukaryotes, ability to grow to very high cell densities and the ability of protein secretions into fermentation media are the additional benefits of yeast expression systems. Moreover, the applications of yeasts in food industry are also accredited them with

Table 3 Cloning of different fungal $\beta$-Xylosidase genes in fungi

\begin{tabular}{|c|c|c|c|c|c|c|}
\hline Source of gene & Gene & Vector & Host & $\begin{array}{l}\text { Molecular mass of the } \\
\text { recombinant enzyme } \\
(\mathrm{kDa})\end{array}$ & $\begin{array}{l}\text { Characteristics of } \\
\text { the recombinant enzyme }\end{array}$ & Reference \\
\hline A. niger GS1 & $x \ln D$ & $\begin{array}{l}\mathrm{pGEM-} \\
\mathrm{T}\end{array}$ & A. niger AB4.1 & 90 & $\begin{array}{l}\text { Temperature }=70{ }^{\circ} \mathrm{C} \mathrm{pH}=3.6 \\
\text { enzyme activity }=4280 \mathrm{Umg} \\
\text { protein }{ }^{-1} \text { half-life }=74 \mathrm{~min} \text { at } 70^{\circ} \mathrm{C} \\
\text { activation energy }=58.9 \mathrm{~kJ} \mathrm{~mol}^{-1}\end{array}$ & $\begin{array}{l}\text { Amaro-Reyes et al. } \\
\text { (2011) }\end{array}$ \\
\hline T. reesei RutC-30 & $b \times 11$ & pAJ401 & S. cerevisiae DBY746 & 49.1 & Enzyme activity $=16.3$ nkat mL ${ }^{-1}$ & $\begin{array}{l}\text { Margolles-Clark et al. } \\
\text { (1996) }\end{array}$ \\
\hline A. niger 90,196 & $x \ln D$ & pDF1 & S. cerevisiae Y294 & 85.1 & $\begin{array}{l}\text { Temperature }=60^{\circ} \mathrm{C} \mathrm{pH}=3.2 \\
\text { stability }=50^{\circ} \mathrm{C} \text { enzyme activ- } \\
\text { ity }=5.3 \mathrm{nkat} \mathrm{mL}^{-1}\end{array}$ & Grange et al. (2001) \\
\hline $\begin{array}{l}\text { A. japonicas } \\
\text { MU-2 }\end{array}$ & $x y / A$ & pPIC9 & P. pastoris GS115 & 113.2 & 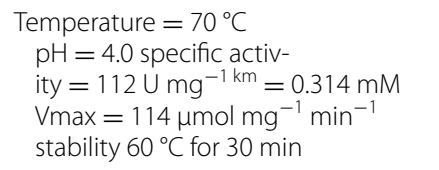 & Wakiyama et al. (2008) \\
\hline H. insolens $Y 1$ & $x y / 3 A$ & pPIC9 & P. pastoris GS115 & 83.2 & $\begin{array}{c}\text { Temperature }=60^{\circ} \mathrm{C} \mathrm{pH}=6 \text { specific } \\
\text { activity }=11.6 \mathrm{Ug} \mathrm{m}^{-1} \mathrm{~K}_{\mathrm{m}}=2.51 \\
\mathrm{mMV} V_{\max }=37.33 \mu \mathrm{mol} \mathrm{min} \mathrm{mg}^{-1}\end{array}$ & Xia et al. (2015) \\
\hline $\begin{array}{l}\text { T. lanuginosus } \\
\text { SSBP }\end{array}$ & tlxyn 1 & pBGPI & P. pastoris GS115 & 52.3 & $\begin{array}{l}\text { Temperature }=50^{\circ} \mathrm{C} \mathrm{pH}=7 \text { specific } \\
\text { activity }=2.29 \mathrm{U} \mathrm{mg}^{-1}\end{array}$ & Gramany et al. (2015) \\
\hline
\end{tabular}


the generally recognized as safe (GRAS) status as they are free of toxins. For heterologous protein expression Saccharomyces cerevisiae, Kluyveromyces lactis, Hansenula polymorpha, P. pastoris and Yarrowia lipolytica are commonly used (Buckholz and Gleeson 1991). The host $S$. cerevisiae (Baker's yeast) has been a good choice for researchers to express recombinant proteins. In 1981 for the first time the expression of recombinant proteins in S. cerevisiae was described but its applications as a host for expression of heterologous proteins in this yeast has diminished due to some limitations. Fermentative mode of growth, instability of recombinant plasmid DNA, hyperglycosylation of secreted proteins and retention of proteins within periplasmic space are the limitations that decrease yields of expressed proteins (Buckholz and Gleeson 1991).

For expression of heterologous proteins, $K$. lactis as a host is known for its applications in food and dairy industries i.e. bovine chymosin. As a platform of recombinant protein expression $K$. lactis furnishes several advantages including applications of both episomal and integrative expression vectors, simple fermentation tools and easy genetic manipulation. D-Xylose and L-arabinose were released by hydrolytic enzymes $\beta$-Xylosidase and $\alpha$-L-arabinofuranosidase, respectively when they were expressed together in S. cerevisiae (Margolles-Clark et al. 1996) from T. reesei (H. jecorina).

With the promoters of alcohol oxidases the methylotrophic yeasts $H$. polymorpha and P. pastoris have been successful as expression systems. Alcohol oxidase is the first enzyme of the pathway of methanol utilization and the promoters were named as AOXI in P. pastoris and $M O X$ in $H$. polymorpha (Macauley-Patrick et al. 2005). In $P$. pastoris both glucose and glycerol repress $A O X I$ promoter, and in $H$. polymorpha glucose represses $A O X I$ promoter while glycerol derepresses $M O X$ promoter to about one-fourth of the induced levels. With $A O X I$ or $M O X$ promoter systems the aerobic growth after induction with methanol resulted in high levels of recombinant proteins (Muller et al. 1998; Voronovsky et al. 2009). Under the control of $A O X I$ or $M O X$ promoters the multicopy strains of yeasts with recombinant gene could be the choice for protein expressions at industrial scale. $Y$. lipolytica which is oleaginous yeast is the upcoming protein expression host as it has many applications for heterologous protein expressions. These advantages include its ability to metabolize acetate, glucose, alcohols and hydrophobic substances such as alkanes, oils and fatty acids, resembling mammalian system of glycosylation, well characterized secretory systems yielding high levels of recombinant proteins (i.e. $2 \mathrm{~g} \mathrm{~L}^{-1}$ ) using defective selection marker, easy screening of multi-copy strains and single integration site usage. The thermotolerant yeast $(H$. polymorpha) was engineered by Voronovsky et al. (2009) coexpressing $\beta$-Xylosidase from $A$. niger and endoxylanase from $T$. reesei by the integration of these genes into $H$. polymorpha genome with its promoter glyceraldehyde-3-phosphate dehydrogenase (GAPDH) gene. The resulted transformants were found to be capable of growing and producing ethanol on a minimal medium at $48^{\circ} \mathrm{C}$ supplemented with birchwood xylan as a sole carbon source.

\section{Recombinant $\beta$-Xylosidases}

The recombinant enzymes are favored over native ones due to certain reasons. In recombinant enzymes we can control production environment as we have choice of different strains and expression vectors for the cloning of an enzymatic system. A more purified product is usually produced from a recombinant enzyme with lesser processing time than native one (Zafar et al. 2014). Usually, fungal $\beta$-Xylosidases are active under more acidic conditions i.e. less than $\mathrm{pH}$ 5.0, whereas bacterial enzymes have their optimum pHs close to $\mathrm{pH} 7$ (Hayashi et al. 2001). The optimum $\mathrm{pH}$ of a recombinant Xyl43B from Clostridium stercorarium was found in an acidic $\mathrm{pH}$ range and the enzyme was slightly active at $\mathrm{pH} 7$ (Suryani et al. 2004). Moreover, it was also found that the recombinant Xyl43B did not need any metal cofactors as the enzyme activity was not influenced by the addition of various metal ions such as $\mathrm{Ba}^{2+}, \mathrm{Ni}^{2+}, \mathrm{Fe}^{2+}, \mathrm{Mg}^{2+}$, $\mathrm{Ca}^{2+}, \mathrm{Mn}^{2+}$ and $\mathrm{Zn}^{2+}$ as chloride salts to enzyme assay mixtures. The xylanase activity of Xyl43B was also found much smaller $\left(0.1 \mathrm{U} \mathrm{mg}^{-1}\right)$ as compared to other enzyme of this type e.g. XynB (about $4000 \mathrm{U} \mathrm{mg}^{-1}$ ) (Fukumura et al. 1995).

The purification of another recombinant $\beta$-Xylosidase (Bxyl) from B. halodurans $\mathrm{C}-125$ was facilitated by the presence of $N$-terminal His-tag and the enzyme was found to be highly expressed as it reached about $5 \%$ of total soluble protein (Liang et al. 2009). The specific activity of Bxyl was found $174 \mathrm{mU} \mathrm{mg}^{-1}$ of protein that was lower than fungal $\beta$-Xylosidases but higher than most of the bacterial xylosidases (Rasmussen et al. 2006). Bxyl was also observed to be very stable because its activity could be maintained for several weeks at $4{ }^{\circ} \mathrm{C}$. Moreover, it is one of the most xylose tolerant enzymes and this quality has made the recombinant enzyme very useful for saccharification of xylan-containing polysaccharides. Suzuki et al. (2010) purified a fungal $\beta$-Xylosidase recombinant enzyme XylB from $A$. oryzae with specific activity of $6.1 \mathrm{U} \mathrm{mg}^{-1}$ of protein but the enzyme didn't show any significant xylosidase activity. Unlike other fungal $\beta$-Xylosidases, XylB was found to be stable at alkaline $\mathrm{pH}$ and it didn't possess substrate ambiguity. Teng et al. (2011) found that the recombinant enzyme PtXyl43 
without predicted signal peptide was secreted in large amount in E. coli. Expression of extracellular secretion and efficient production of this enzyme in E. coli has increased the importance of PtXy143 for having potential industrial applications.

\section{Regulation and production of $\boldsymbol{\beta}$-Xylosidases}

For the production of biofuels, so far the mesophilic engineered organisms or enzymes have been the favored choices. The reasons for this choice are mainly the deep knowledge of their metabolic pathways and genetic tools that have been established to engineer those. But in the last few years, due to stoutness and versatility of thermophilic organisms some alternative approaches have also been made on these organisms and their enzymes (Barnard et al. 2010). It has been observed in most of the fungi that the expression of xylanolytic enzymes is subjected to specific induction in xylan or xylose presence and to carbon catabolite repression that is mediated by the catabolite repressible entities (CreA) repressor (Prathumpai et al. 2004). The transcription activator XlnR also mediates the regulation of $\beta$-Xylosidases that regulates the expression of different genes which are involved in the degradation of xylan (Stricker et al. 2008). The transcription and repression of $x \ln R$ gene is controlled by carbon sources and CreA respectively (Tamayo et al. 2008) therefore, a balance between transcription of $X \ln R$ factor and CreA repressor is responsible for transcription regulation of xylanolytic enzymes such as $\beta$-Xylosidases. From T. emersonii the gene encoding $\beta$-Xylosidase $(b x l 1)$ was isolated and cloned in E. coli (Reen et al. 2003). The inferred amino acid sequence reveals homology with $\beta$-Xylosidase gene products from $T$. reesei, $A$. nidulans and $A$. niger and with some $\beta$-Xylosidase genes belonging to $\mathrm{GH}$ family 3 . It was found that $\beta$-Xylosidase gene was induced by xylan, D-xylose and also by methyl- $\beta-D-$ xylopyranoside but not with high concentrations. There are six CreA binding sites in the promoter of $\beta$-Xylosidase (bxl1) gene and the observed repression by D-glucose was suggested to be mediated by this catabolite repressor. To regulate and secrete inducible enzymes the catabolic repression plays a vital role. The catabolic repression of $\beta$-Xylosidases at molecular level has been related with the presence of CreA binding sites in their promoters and this carbon catabolite repression that is mediated by CreA has also been reported in other fungal genes (Knob et al. 2010).

The induction of mutations in the parental fungal strains using various mutagens has been the most efficient practice for enhanced productions of important enzymes (Mustafa et al. 2014). Increased levels of regulatory proteins and co-factors of different fungal mutants are considered responsible for enhanced activities of
$\beta$-Xylosidases. Maximum production of $\beta$-Xylosidase was achieved (728 $\mathrm{IUg}^{-1}$ substrate, $\mathrm{Y}_{\mathrm{P} / \mathrm{S}}$ ) from $\mathrm{H}$. lanuginosa M7D mutant grown on Vogel's medium containing xylan. $K_{m}$ value for purified mutant enzyme was $1.8 \mathrm{~mm}$ with optimum $\mathrm{pH} 8.5$ and temperature of $60^{\circ} \mathrm{C}$ (Bokhari et al. 2010). In another study, maximum volumetric production of $\beta$-Xylosidase from $C$. biazotea mutant grown on xylan was achieved $30.7 \mathrm{IU} / \mathrm{l} / \mathrm{h}$ which was 2.29-fold enhanced over its wild strain (Rajoka et al. 1997). An enhanced production of $\beta$-Xylosidase was also achieved from $K$ marxianus M125 mutant up to 1.5 to twofold more than that from the wild strain. The stability of the purified enzyme was found good at a temperature of $60^{\circ} \mathrm{C}$ and $\mathrm{pH}$ 5.0-7.0. The results suggested that an induction mechanism was involved in the regulation of $\beta$-Xylosidase biosynthesis which enhanced specific yield of enzyme $\left(\mathrm{Y}_{\mathrm{p} / \mathrm{x}}\right)$ up to 59-fold in the mutant cells (Rajoka and Khan 2005). To regulate and secrete inducible enzymes the catabolite repression plays a vital role which has also been studied in K. marxianus var. marxianus. Due to mixed inductive or repressive effects an increased production of $\beta$-Xylosidase in xylose medium with glucose was observed $\left(6.8 \mathrm{IU} \mathrm{mL}^{-1}\right)$ in $K$. marxianus var. marxianus (Rajoka 2007). When regulation of $\beta$-Xylosidase production was studied in Cellulomonas flavigena, maximum yield of the enzyme was obtained with xylose (monomeric sugar) in Dubos medium. Cellobiose was observed as best inducer and xylan as best substrate of $\beta$-Xylosidase among disaccharides and polymeric substances respectively (Rajoka 2005).

In general, during $\beta$-Xylosidase productions the monosaccharides play roles as strong repressors while disaccharides and polysaccharides act as inducers. During the growth of $\beta$-Xylosidase on monosaccharides a very low quantity of mRNA is produced for enzyme and the expression of enzyme is modulated by CreA on xylose or glucose in filamentous fungi. The efficiency of $\beta$-Xylosidase inducers can be checked through their binding affinity with those of regulatory macromolecules and their actual concentration inside the cell.

\section{Coding regions of $\beta$-Xylosidase gene}

$\beta$-Xylosidases belong to glycosyl hydrolases families 3, $39,43,51,52$ and 54 , but so far the fungal enzymes are described only from families 3, 43 and 54 . In databases s2 is the only $\beta$-Xylosidase gene which has been completely sequenced from Penicillium herquei IFO 4674. The gene consists of 1005 base pairs and does not contain any introns. Although, the enzyme is a cell surface associated protein but it encodes 335 amino acid protein without any apparent signal peptide (Ito et al. 2003). In addition to this sequence, a partial gene sequence of $\beta$-Xylosidase of $290 \mathrm{bp}$ has also been reported from P. purpurogenum 
(Ito et al. 2003). A high degree of similarity is possessed by these both enzymes with glycosyl hydrolases family 43. It is an interesting observation that from organisms with phylogenetic closeness with Penicillium such as Aspergillus are not found in family 43 that contains mainly xylosidases from bacterial origins but found in glycosyl hydrolases family 3 . However, the open reading frames (ORFs) from some fungi whose entire genome has been sequenced encode for hypothetical proteins having similarity with Penicillium $\beta$-Xylosidases described above. $\beta$-Xylosidase genes from $A$. nidulans (accession number XP 405614 in NCBI Protein Database), Magnaphorte grisea (accession number XP 366835 in NCBI Protein Database) and Neurospora crassa (Galagan et al. 2003) has been isolated and sequenced. In addition, a partial sequence of $\beta$-Xylosidase from $A$. oryzae (Ito et al. 2003) and from Cochliobolus carbonum $\beta$-Xylosidase (Wegener et al. 1999) also belong to family 43. It has been suggested from these findings that fungal $\beta$-Xylosidases are structurally of two types and are categorized into two different families of glycosyl hydrolases i.e. 3 and 43.

\section{Comparisons of amino acid sequences of fungal $\beta$-Xylosidases}

A multiple sequence alignment was performed to compare sequences of $\beta$-Xylosidases from ten different fungal species (Fig. 2). The amino acid sequence of $\beta$-Xylosidase from A. fumigatus was aligned and compared with $\beta$-Xylosidases from nine different fungal species. It showed $\beta$-Xylosidase similarities of $95 \%$ from Neosartorya fischeri, 70 \% from Rasamsonia emersonii, $69 \%$ from Talaromyces stipitatus, $60 \%$ from Gloeophyllum trabeum, 59 \% from Hydnomerulius pinastri, $58 \%$ from Oidiodendron maius, 58 \% from Serpula lacrymans, 58 \% from Heterobasidion irregular and 59 \% from Phanerochaete carnosa.

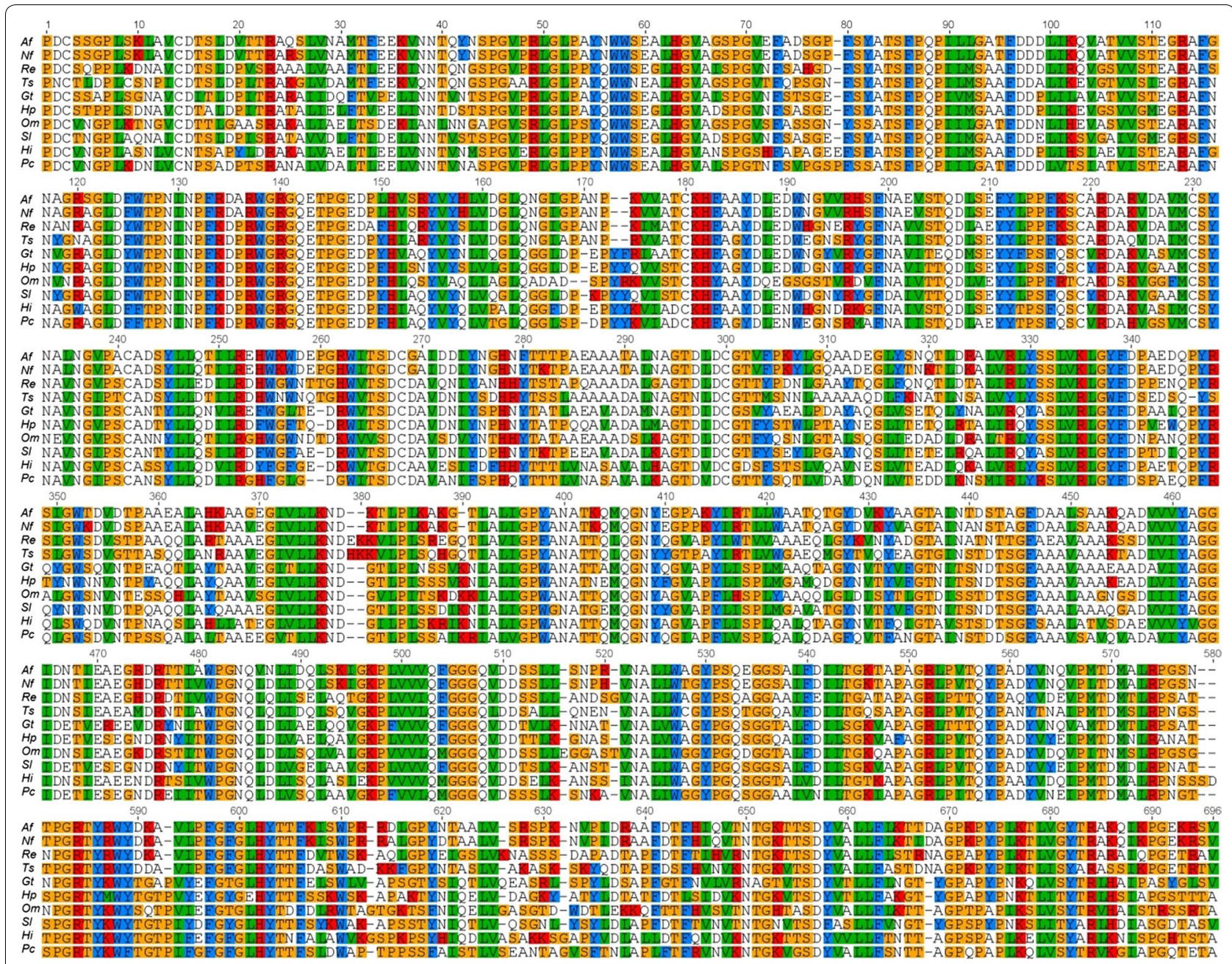

Fig. 2 Alignment of $\beta$-Xylosidase enzymes from ten fungal species. Xylosidases are from are from Aspergillus fumigatus (Af), Neosartorya fischeri (Nf), Rasamsonia emersonii (Re), Talaromyces stipitatus (Ts), Gloeophyllum trabeum (Gt), Hydnomerulius pinastri (Hp), Oidiodendron maius (Om), Serpula lacrymans (SI), Heterobasidion irregulare (Hi), Phanerochaete carnosa (PC) 
Through hydrophobic cluster analysis many $\beta$-Xylosidases have been classified into three different families i.e. 39, 43 and 52 (Henrissat and Bairoch 1993) and among these three distinct groups of $\beta$-Xylosidases, $X y l A$ (a $\beta$-Xylosidase gene from $A$. oryzae) gene did not show any similarity to these groups. However, $X y l A$ gene showed $70 \%$ similarities with $X \ln D$ from $A$. nidulans, $64 \%$ with $X \ln D$ from $A$. niger and $63 \%$ with $B x l I$ from T. reesei. The sequence similarities have shown that all these fungal $\beta$-Xylosidase genes belong to family 3 glycoside hydrolase (GH) (Kitamoto et al. 1999). Moreover, A. oryzae has also been reported to have two cell wallbinding and three extracellular types of $\beta$-Xylosidases (Hashimoto et al. 1999). Several highly conserved regions among XylA of $A$. oryzae, XlnD of $A$. nidulans, BxlI of T. reesei and $X \ln D$ of $A$. niger have also been found that have been hypothesized to be involved in substrate binding, catalytic reactions or both (Kitamoto et al. 1999). An Asp residue of one putative active-site has been thought to be playing a role in catalytic activity as determined for $\beta$-glucosidase A3 from $A$. wentii and it was also found to be conserved in XylA of A. oryzae (Asp-310) (Bause and Legler 1980).

A $\beta$-Xylosidase $X y l A$ was also reported from $A$. japonicus and its BLAST search gave high degrees of similarities with other $\beta$-Xylosidases of GH family-3 (Wakiyama et al. 2008). It showed $69 \%$ sequence similarity with $X \ln D$ from A. niger (van Peij et al. 1997), 69 \% with Xawl from A. awamori (Kurakake et al. 2005), 69 \% with XylA from A. fumigatus (CM000169; locus tag AFUA_1G16920), $68 \%$ with XylA from A. oryzae (Kitamoto et al. 1999), $66 \%$ with Bxl1 from T. emersonii (Reen et al. 2003), $65 \%$ with $X \ln D$ from $A$. nidulans (Perez-Gonzalez et al. 1998), $64 \%$ with Bxl1 from T. reesei (Margolles-Clark et al. 1996), $63 \%$ with $\beta$-Xylosidase from A. clavatus and $48 \%$ with $\beta$-Xylosidase from $N$. fischeri (DS027697; locus tag NFIA_003180).

A BLAST analysis for another $\beta$-Xylosidase Xyp 1 from a plant-pathogenic fungus $C$. carbonurn yielded some surprising results as it did not show any similarity with any of fungal $\beta$-Xylosidases present in database (Altschul et al. 1990) but it showed identity with regard to its size and primary sequence with two bacterial $\beta$-Xylosidases i.e. $30 \%$ overall identity each with Bacteroides ovatus and Prevotella ruminicola (Whitehead and Hespell 1990; Gasparic et al. 1995). Surprisingly, no obvious signal peptide was present in any of these two bacterial xylosidases therefore, P. ruminicola $\beta$-Xylosidase was supposed to be present in cytoplasm (Gasparic et al. 1995).

Reen et al. (2003) compared the deduced amino acid sequence of $b x l 1$ gene encoding $\beta$-Xylosidase from a thermophilic fungus T. emersonii and compared with the sequences available in databases. The sequence of $b x l 1$ showed identities with $\beta$-Xylosidase genes following $73 \%$ from $T$. reesei, $64 \%$ from $A$. oryzae, $63 \%$ with $A$. nidulans and $61 \%$ with $A$. niger. Homolog of $b x l 1$ gene with $\beta$-glucosidases of GH family-3 was also observed with identity values of $38 \%$ from Xanthomonas campestris, $33 \%$ from Bacillus halodurans and $22 \%$ from T. Reesei with Asp311 appeared in majority of $\beta$-glucosidases of GH family-3 as conserved residue and suggested that it is a part of active site of $\beta$-glucosidases of GH family-3 (Coutinho and Henrissat 1999).

Surprisingly, Margolles-Clark et al. (1996) reported that amino acid sequence of $B X L I$ gene from $T$. reesei didn't show similarities with any reported $\beta$-Xylosidases from the families of 39, 43 and 52. In spite of lacking the $\beta$-glucosidase activity the gene showed significant similarities with family 3 enzymes and this family is highly conserved as it includes $\beta$-glucosidases only. Another $\beta$-Xylosidase gene $(X a w l)$ was deduced from A. awamori and searched for its homology (Kurakake et al. 2005). The amino acid sequence of the gene showed similarities with $\beta$-Xylosidases from $A$. niger having $98 \%$ (van Peij et al. 1997) and $94 \%$ (Grange et al. 2000) identities with DNA sequence.

A novel $\beta$-Xylosidase gene (PtXyl43) was isolated from thermophilic fungus Paecilomyces thermophile, cloned and studied for its homology (Teng et al. 2011). The gene showed high identities with some putative fungal $\beta$-Xylosidases of GH family-43. It gave similarities with $\beta$-Xylosidases from Penicillium herquei 73 \% (Ito et al. 2003), A. fumigatus $72 \%$, N. fischeri $72 \%$, Penicillium chrysogenum $71 \%$, A. flavus $70 \%$ and A. oryzae $70 \%$.

Currently, $\beta$-Xylosidases from different fungi have been classified into five glycosyl hydrolase $(\mathrm{GH})$ families i.e. 3, 39, 43, 52 and 54. Most of the $\beta$-Xylosidases from fungi have shown high sequence similarities with other fungal $\beta$-Xylosidases but Xyp1 from a plant-pathogenic fungus Cochliobolus carbonurn did not show similarity with fungal $\beta$-Xylosidases and it showed identity with bacterial $\beta$-Xylosidases of B. ouatus and P. ruminicola.

\section{Concluding remarks}

Degradation of a complex mixture of biomass is an essential evil for the production of easily accessible sugar residues in industrial processes. Enhanced production of industrial biocatalysts with novel and desirable characteristics have better prospects in terms of both increased economic pressure and industrial developments. Overproduction of $\beta$-Xylosidase could not receive much attention due to limited information regarding crystallographic structure of the enzyme; however recombinant enzyme with $\mathrm{pH}$ and temperature stability is a good alternative to the native enzyme for its effective utilization. Despite great hopes placed in biotechnological 
advances, hyperproduction of enzymes is still challenging. Although heterologous expression of $\beta$-Xylosidase in hosts such as E. coli, P. pastoris and S. cerevisiae is attractive due to less interfering activities, glycosylation and post translational modification complicate the issue.

Exploring new fungal hosts capable of producing recombinant $\beta$-Xylosidases is still a possibility. To improve and develop fungal expression systems using approaches of genetic engineering through further technical advancements will surely help in hyperexpression of heterologous $\beta$-Xylosidases from different fungi. Hyperproduction of the enzyme can be achieved by conventional mutagenesis of the strains or by using knockout strains as a host. Homologous expression can also be an alternative but with major problem of contamination of endogenous hydrolases. Contamination can be avoided by using His tags engineered into a protein for purification. Thus P. pastoris and S. cerevisiae can be a reasonable host for medium scale production of $\beta$-Xylosidase.

$\beta$-Xylosidases have high amino acid sequence similarities from different fungi. Several $\beta$-Xylosidases have been purified from bacteria and fungi, and studied for their biochemical characterization. In general, based on their amino acid sequence similarities, they are classified into five different families of glycosyl hydrolases (GH) which include GH families 3, 39, 43, 52 and 54. Most of the reported fungal enzymes belong to $\mathrm{GH}$ family- 3 of $\beta$-Xylosidases in spite of they have been reported from other GH families as well. Sequence similarities searches of $\beta$-Xylosidases on databases play an important role to identify and classify some novel $\beta$-Xylosidase genes from different fungi.

\section{Authors' contributions}

GM and MIR designed and carried out the molecular studies. GM analyzed the data for comparative sequence studies. GM and SK drafted the manuscript and AJ provided conceptual and technical guidance for all aspects of the manuscript. All authors read and approved the final manuscript.

\section{Author details}

${ }^{1}$ Department of Biochemistry, University of Agriculture, Faisalabad 38040, Pakistan. ${ }^{2}$ Department of Chemistry, Government College Women University, Faisalabad, Pakistan. ${ }^{3}$ Department of Bioinformatics and Biotechnology, Government College University, Faisalabad, Pakistan.

\section{Competing interests}

The authors declare that they have no competing interests.

Received: 5 April 2016 Accepted: 6 April 2016

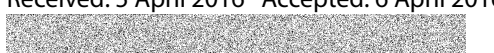

\section{References}

Ahmed S, Imdad SS, Jamil A. Comparative study for the kinetics of extracellular xylanases from Trichoderma harzianum and Chaetomium thermophilum. Electron J Biotechnol. 2012;15:1-8

Ahmed S, Riaz S, Jamil A. Molecular cloning of fungal xylanases: an overview. Appl Microbiol Biotechnol. 2009;84:19-35.
Altschul SF, Gish W, Miller W, Myers EW, Lipman DJ. Basic local alignment search tool. J Mol Biol. 1990;215:403-10.

Amaro-Reyes A, Garcia-Almendarez BE, Vazquez-Mandujano DG, Amaya-Llano S, Castano-Tostado E, Guevara-Gonzalez RG, Loera O, Regalado C. Homologue expression of a $\beta$-Xylosidase from native Aspergillus niger. J Ind Microbiol Biotechnol. 2011;38:1311-9.

Baba T, Shinke R, Nanmori T. Identification and characterization of clustered genes for thermostable xylan-degrading enzymes, $\beta$-Xylosidase and xylanase, of Bacillus stearothermophilus 21. Appl Environ Microbiol. 1994;60:2252-8.

Banerjee G, Scott-Craig JS, Walton JD. Improving enzymes for biomass conversion: a basic research perspective. Published Bioenerg Res. 2010;3:82-92

Barnard D, Casanueva A, Tuffin M, Cowan D. Extremophiles in biofuel synthesis. Environ Technol. 2010;31:871-88.

Bause $E$, Legler $\mathrm{G}$. Isolation and structure of a tryptic glycopeptide from the active site of beta-glucosidase A3 from Aspergillus wendtii. Biochim Biophys Acta. 1980;626:459-65.

Biswas SR, Jana SC, Mishra AK, Nanda G. Production, purification, and characterization of xylanase from a hyperxylanolytic mutant of Aspergillus ochraceus. Biotechnol Bioeng. 1990;35:244-51.

Bokhari SAl, Latif F, Akhtar MW, Rajoka MI. Characterization of a $\beta$-Xylosidase produced by a mutant derivative of Humicola lanuginosa in solid state fermentation. Ann Microbiol. 2010;60:21-9.

Buckholz RG, Gleeson MAG. Yeast systems for the commercial production of heterologous proteins. Nat Biotechnol. 1991;9:1067-72.

Chen X, Meng K, Shi P, Bai Y, Luo H, Huang H, Yuan T, Yang P, Yao B. High-level expression of a novel Penicillium endo-1,3(4)- $\beta$-D-glucanase with high specific activity in Pichia pastoris. J Ind Microbiol Biotechnol. 2012a;39:869-76.

Chen Z, Jia H, Yang Y, Yan Q, Jiang Z, Teng C. Secretory expression of a $\beta$-Xylosidase gene from Thermomyces lanuginosus in Escherichia coli and characterisation of its recombinant enzyme. Lett Appl Microbiol. 2012b;55:330-7.

Coutinho PM, Henrissat B. Carbohydrate-active enzymes: an integrated database approach. In: Gilbert GDHJ, Henrissat B, Svensson B, editors. Recent advances in carbohydrate bioengineering. Cambridge: The Royal Society of Chemistry; 1999. p. 3-12.

Curotto E, Concha M, Campos V, Milagres AMF, Duran N. Production of extracellular xylanases by Penicillium janthinellum. Appl Biochem Biotechnol. 1994:48:107-16.

Diolez A, Langin T, Gerlinger C, Brygoo Y, Daboussi MJ. The nia gene of Fusarium oxysporum: isolation, sequence and development of a homologous transformation system. Gene. 1993:131:61-7.

Fukumura M, Sakka K, Shimada K, Ohmiya K. Nucleotide sequence of the Clostridium stercorarium xynB gene encoding an extremely thermostable xylanase, and characterization of the translated product. Biosci Biotechnol Biochem. 1995;59:40-6.

Galagan JE, Calvo SE, Borkovich KA, Selker EU, Read ND, Jaffe D, FitzHugh W, Ma LJ, Smirnov S, Purcell S, Rehman B. The genome sequence of the filamentous fungus Neurospora crassa. Nature. 2003;422:859-68.

Gareia-Pedrajas MD, Roncero MIG. A homologous and self-replicating system for efficient transformation of Fusarium oxysporum. Curr Genet. 1996;29:191-8.

Gasparic A, Martin J, Daniel AS, Flint HJ. A xylan hydrolase gene cluster in Prevotella ruminicola $B_{1} 4$ : sequence relationships, synergistic interactions, and oxygen sensitivity of a novel enzyme with exoxylanase and $\beta$-(1,4)-xylosidase activities. Appl Environ Microbiol. 1995;61:2958-64.

Girio FM, Fonseca C, Carvalheiro F, Duarte LC, Marques S, Bogel-Łukasik R. Hemicellulose for fuel ethanol: a review. Bioresource Technol. 2010;10:4775-800.

Gramany V, Khan Fl, Govender A, Bisetty K, Singh S, Permaul K. Cloning, expression, and molecular dynamics simulations of a xylosidase obtained from Thermomyces lanuginosus. J Biomol Struct Dyn. 2015. doi:10.1080/ 07391102.2015 .1089186$.

Grange DCL, Pretorius IS, Claeyssens M, van ZyI WH. Degradation of xylan to D-Xylose by recombinant Saccharomyces cerevisiae coexpressing the Aspergillus niger $\beta$-Xylosidase $(x / n D)$ and the Trichoderma reesei xylanase II (xyn2) Genes. Appl Environ Microbiol. 2001;67:5512-9.

Grange LDC, Pretorius IS, ZyI WH. Co-expression of the Trichoderma reesei beta-xylanase (XYN2) and the Aspergillus niger beta-xylosidase (XLND) 
in the yeast Saccharomyces cerevisiae. Appl Microbiol Biotechnol. 2000;54:195-200.

Gruber F, Visser J, Kubicek CP, de Graaff LH. The development of a heterologous transformation system for the cellulolytic fungus Trichoderma reesei based on a pyrG-negative mutant strain. Curr Genet. 1990;18:71-6.

Guangtao Z, Hartl L, Schuster A, Polak S, Schmoll M, Wang T, Seidl V, Seiboth B. Gene targeting in a nonhomologous end joining deficient Hypocrea jecorina. J Biotechnol. 2009;139:146-51.

Guangtao Z, Seiboth B, Wen C, Yaohua Z, Xian L, Wang T. A novel carbon source-dependent genetic transformation system for the versatile cell factory Hypocrea jecorina (anamorph Trichoderma reesei). FEMS Microbiol Lett. 2010;303:26-32.

Hashimoto T, Morishita M, Iwashita K, Shimoi H, Nakata Y, Tsuji Y, Ito K. Production and some properties of salt-tolerant $\beta$-Xylosidase from a shoyu koji mold, Aspergillus oryzae in solid and liquid cultures. J Biosci Bioeng. 1999;88:479-83.

Hayashi S, Ohno T, Yokoi H. Purification and properties of the cell-associated $\beta$-Xylosidase from aureobasidium. J Ind Microbiol Biotechnol. 2001;26:276-9.

Henrissat B, Bairoch A. New families in the classification of glycosyl hydrolases based on amino acid sequence similarities. Biochem J. 1993;293:781-8.

Hudson RC, Schofield LR, Coolbear T, Daniel RM, Morgan HW. Purification and properties of an aryl $\beta$-Xylosidase from a cellulolytic extreme thermophile expressed in Escherichia coli. Biochem J. 1991;273:645-50.

Hyun YJ, Kim B, Kim DH. Cloning and characterization of ginsenoside ra1hydrolyzing $\beta$-D-xylosidase from Bifidobacterium breve K-110. J Microbiol Biotechnol. 2012;22:535-40.

Ito T, Yokoyama E, Sato H, Ujita M, Funaguma T, Furukawa K, Hara A. Xylosidases associated with the cell surface of Penicilliium herquei IFO 4674. J Biosci Bioeng. 2003;96:354-9.

Juturu V, Wu JC. Heterologous expression of $\beta$-Xylosidase gene from Paecilomyces thermophila in Pichia pastoris. World J Microbiol Biotechnol. 2013;29:249-55.

Kanna M, Yano S, Inoue H, Fujii T, Sawayama S. Enhancement of $\beta$-Xylosidase productivity in cellulase producing fungus Acremonium cellulolyticus. AMB Express. 2011;1:1-8.

Khang CH, Park SY, Lee YH, Kang S. A dual selection based targeted gene replacement tool for Magnaporthe grisea and Fusarium oxysporum. Fungal Genet Biol. 2005;42:483-92.

Kim YA, Yoon KH. Characterization of a Paenibacillus woosongensis $\beta$-Xylosidase/a-arabinofuranosidase produced by recombinant Escherichia coli. J Microbiol Biotechnol. 2010;20:1711-6.

Kitamoto N, Yoshino S, Ohmiya K, Tsukagoshi N. Sequence analysis, overexpression, and antisense inhibition of a $\beta$-Xylosidase gene, xylA, from Aspergillus oryzae KBN616. Appl Environ Microbiol. 1999;65:20-4.

Knob A, Terrasan CRF, Carmona EC. $\beta$-Xylosidases from filamentous fungi: an overview. World J Microbiol Biotechnol. 2010;26:389-407.

Korona B, Korona D, Bielecki S. Efficient expression and secretion of two coproduced xylanases from Aspergillus niger in Pichia pastoris directed by their native signal peptides and the Saccharomyces cerevisiae a-mating factor. Enzyme Microb Technol. 2006;39:683-9.

Kousar S, Mustafa G, Jamil A. Microbial xylosidases: production and biochemical characterization. Pak J Life Soc Sci. 2013;11:85-95.

Krogh KBR, Morkeberg A, Jorgensen H, Frisvad JHC, Ols-son L. Screening genus Penicillium for producers of cellulolytic and xylanolytic enzymes. Appl Biochem Biotechnol. 2004;1 14:389-401.

Kumar S, Ramon D. Purification and regulation of the synthesis of a $\beta$-Xylosidase from Aspergillus nidulans. FEMS Microbiol Lett. 1996:135:287-93.

Kurakake M, Fujii T, Yata M, Okazaki T, Komaki T. Characteristics of transxylosylation by $\beta$-Xylosidase from Aspergillus awamori K4. Biochem Biophys Acta. 2005;1726:272-9.

Kvesitadze GE, Kvesitadze EG, Kvesitadze GI. Industrially important enzymes from microorganisms. Ann Agrar Sci. 2014;10(2):1-8.

Lee YE, Zeikus JG. Genetic organization, sequence and biochemical characterization of recombinant $\beta$-Xylosidase from Thermoanaerobacterium saccharolyticum strain B6A-RI. J Gen Microbiol. 1993;139:1235-43.

Liang Y, Li X, Shin H, Chen RR, Mao Z. Expression and characterization of a xylosidase (Bxyl) from Bacillus halodurans C-125. Chin J Biotech. 2009:25:1386-93.
Lorenz WW, Wiegel J. Isolation, analysis, and expression of two genes from Thermoanaerobacterium sp. strain JW/SL YS485: a $\beta$-Xylosidase and a novel acetyl xylan esterase with cephalosporin C deacetylase activity. J Bacteriol. 1997;179:5436-41.

Macauley-Patrick S, Fazenda ML, McNeil B, Harvey LM. Heterologous protein production using the Pichia pastoris expression system. Yeast. 2005;22:249-70.

Mach RL, Schindler M, Kubicek CP. Transformation of Trichoderma reesei based on hygromycin B resistance using homologous expression signals. Curr Genet. 1994;25:567-70.

Margolles-Clark E, Tenkanen M, Nakari-Setala T, Penttila M. Cloning of genes encoding $a$-L-arabinofuranosidase and $\beta$-Xylosidase from Trichoderma reesei by expression in Saccharomyces cerevisiae. Appl Environ Microbiol. 1996;62:3840-6.

Menon V, Prakash G, Rao M. Value added products from hemicellulose: biotechnological perspective. Glob J Biochem. 2010;1:36-67.

Mergulhao FJM, Summers DK, Monteiro GA. Recombinant protein secretion in Escherichia coli. Biotechnol Adv. 2005;23:177-202.

Messner P. Prokaryotic protein glycosylation is rapidly expanding from "curiosity" to "ubiquity". ChemBioChem. 2009;10:2151-4.

Montibeller VW, de Souza Vandenberghe LP, Amore A, Soccol CR, Birolo L, Vinciguerra R, Salmon DNX, Spier MR, Faraco V. Characterization of hemicellulolytic enzymes produced by aspergillus niger nrrl 328 under solid state fermentation on soybean husks. BioResources. 2014;9:7128-40.

Moon YH, lakiviak M, Bauer S, Mackie RI, Cann IKO. Biochemical analyses of multiple endoxylanases from the rumen bacterium Ruminococcus albus 8 and their synergistic activities with accessory hemicellulose-degrading enzymes. Appl Environ Microbiol. 2011;77:5157-69.

Morais S, Barak Y, Hadar Y, Wilson DB, Shoham Y, Lamed R, Bayer EA. Assembly of xylanases into designer cellulosomes promotes efficient hydrolysis of the xylan component of a natural recalcitrant cellulosic substrate. Mbio. 2011:2:1-11.

Muller S, Sandal T, Kamp-Hansen P, Dalboge H. Comparison of expression systems in the yeasts Saccharomyces cerevisiae, Hansenula polymorpha, Kluyveromyces lactis, Schizosaccharomyces pombe and Yarrowia lipolytica. Cloning of two novel promoters from Yarrowia lipolytica. Yeast. 1998;14:1267-83.

Mullins ED, Chen X, Romaine P, Raina R, Geiser DM, Kang S. Agrobacteriummediated transformation of Fusarium oxysporum: an efficient tool for insertional mutagenesis and gene transfer. Phytopathology. 2001;91:173-80.

Mustafa G, Jamil A. Cloning and phylogenetic analysis of an actin encoding DNA fragment from filamentous fungus Trichoderma harzianum. Int J Agric Biol. 2013;15:1013-6.

Mustafa G, Tahir A, Asgher M, Rahman MU, Jamil A. Comparative sequence analysis of citrate synthase and 185 ribosomal DNA from a wild and mutant strains of Aspergillus niger with various fungi. Bioinformation. 2014:10:1-7.

Ohta K, Fujimoto H, Fujii S, Wakiyama M. Cell-associated $\beta$-Xylosidase from Aureobasidium pullulans ATCC 20524: purification, properties, and characterization of the encoding gene. J Biosci Bioeng. 2010;110:152-7.

Penttila M, Nevalainen H, Ratto M, Salminen E, Knowles J. A versatile transformation system for the cellulolytic filamentous fungus Trichoderma reesei. Gene. 1987;61:155-64.

Perez-Gonzalez JA, van Peij NNME, Bezoen A, MacCabe AP, Ramon D, de Graaff LH. Molecular cloning and transcriptional regulation of the Aspergillus nidulans $x / n D$ gene encoding a $\beta$-Xylosidase. Appl Environ Microbiol. 1998;64:1412-9.

Peterbauer CK, Heidenreich E, Baker RT, Kubicek CP. Effect of benomyl and benomyl resistance on cellulase formation by Trichoderma reesei and Trichoderma harzianum. Can J Microbiol. 1992;38:1292-7.

Prathumpai W, Mcintyre M, Nielsen J. The effect of CreA in glucose and xylose catabolism in Aspergillus nidulans. Appl Microbiol Biotechnol. 2004;63:748-53.

Qian Y, Yomano LP, Preston JF, Aldrich HC, Ingram LO. Cloning, characterization, and functional expression of the Klebsiella oxytoca xylodextrin utilization operon (xynTB) in Escherichia coli. Appl Environ Microbiol. 2003;69:5957-67.

Rahman AKMS, Sugitani N, Hatsu M, Takamizawa K. A role of xylanase, a-L-arabinofuranosidase, and xylosidase in xylan degradation. Can J Microbiol. 2003;49:58-64. 
Rajoka MI. Regulation of synthesis of endo-xylanase and $\beta$-Xylosidase in Cellulomonas flavigena: a kinetic study. World J Microbiol Biotechnol. 2005;21:463-9.

Rajoka MI. Kinetic parameters and thermodynamic values of $\beta$-Xylosidase production by Kluyveromyces marxianus. Bioresour Technol. 2007;98:2212-9.

Rajoka MI, Khan S. Hyper-production of a thermotolerant $\beta$-Xylosidase by a deoxy-D-glucose and cycloheximide resistant mutant derivative of Kluyveromyces marxianus PPY 125. Electron J Biotechnol. 2005;8:58-65.

Rajoka MI, Bashir A, Malik KA. Mutagenesis of Cellulomonas biazotea for enhanced production of xylanases. Bioresour Technol. 1997:62:99-108.

Rasmussen LE, Sorensen HR, Vind J, Viksø-Nielsen A. Mode of action and properties of the $\beta$-Xylosidase from Talaromyces emersonii and Trichoderma reesei. Biotechnol Bioeng. 2006;94:869-76.

Reen FJ, Murray PG, Tuohy MG. Molecular characterisation and expression analysis of the first hemicellulase gene (bx/1) encoding $\beta$-Xylosidase from the thermophilic fungus Talaromyces emersonii. Biochem Biophys Res Commun. 2003:305:579-85.

Reese ETA, Maguire A, Parrish FW. Production of $\beta$-D-xylopyranosidase by fungi. Can J Microbiol. 1973;19:1065-74.

Sakka K, Kojima Y, Yoshikawa K, Shimada K. Cloning and expression in Escherichia coli of thermophilic Clostridium stercorarium strain strain F-9 genes related to xylan hydrolysis. Agric Biol Chem. 1990;54:337-42.

Saleem M, Aslam F, Akhtar MS, Tariq M, Rajoka MI. Characterization of a thermostable and alkaline xylanase from Bacillus sp. and its bleaching impact on wheat straw pulp. World J Microbiol Biotechnol. 2012;28:513-22.

Schuster A, Kubicek CP, Friedl MA, Druzhinina IS, Schmoll M. Impact of light on Hypocrea jecorina and the multiple cellular roles of ENVOY in this process. BMC Genom. 2007;8:449-65.

Sewell GW, Utt EA, Hespell RB, Mackenzie KF, Ingram LO. Identification of the Butyrivibrio fibrisolvens xylosidase gene (xylB) coding region and its expression in Escherichia coli. Appl Environ Microbiol. 1989;55:306-11.

Shao W, Xue Y, Wu A, Kataeva I, Pei J, Wu H, Wiegel J. Characterization of a Novel $\beta$-Xylosidase, XylC, from Thermoanaerobacterium saccharolyticum JW/SL-YS485. Appl Environ Microbiol. 2011;77:719-26.

Shi H, Li X, Gu H, Zhang Y, Huang Y, Wang L, Wang F. Biochemical properties of a novel thermostable and highly xylose-tolerant beta-xylosidase/ alpha-arabinosidase from Thermotoga thermarum. Biotechnol Biofuels. 2013;6:27-37.

Singh A, Kuhad RC, Kumar M. Xylanase production by a hyperxylanolytic mutant of Fusarium oxysporum. Enzyme Microb Technol. 1995;17:551-3.

Sommer B, Friehs K, Flaschel E. Efficient production of extracellular proteins with Escherichia coli by means of optimized coexpression of bacteriocin release proteins. J Biotechnol. 2010;145:350-8.

Stewart EJ, Aslund F, Beckwith J. Disulfide bond formation in the Escherichia coli cytoplasm: an in vivo role reversal for the thioredoxins. EMBO J. 1998:17:5543-50.

Stricker A, Mach R, de Graaff LH. Regulation of transcription of cellulase and hemicellulases-encoding genes in Aspergillus niger and Hypocrea jecorina (Trichoderma reesei). Appl Microbiol Biotechnol. 2008;78:211-20.

Suryani Kimura T, Sakka K, Ohmiya K. Sequencing and expression of the gene encoding the clostridium stercorarium $\beta$-Xylosidase Xyl43B in Escherichia coli. Biosci Biotechnol Biochem. 2004;68:609-14.

Suzuki S, Fukuoka M, Ookuchi H, Sano M, Ozeki K, Nagayoshi E, Takii Y, Matsushita M, Tada S, Kusumoto Ken-Ichi, Kashiwagi Y. Characterization of Aspergillus oryzae glycoside hydrolase family $43 \beta$-Xylosidase expressed in Escherichia coli. J Biosci Bioeng. 2010;109:115-7.

Suzuki T, Kitagawa E, Sakakibara F, Ibata K, Usui K, Kawai K. Cloning, expression, and characterization of a family $52 \beta$-Xylosidase gene (XysB) of a multiple-xylanase-producing bacterium, Aeromonas caviae ME-I. Biosci Biotechnol Biochem. 2001;65:487-94.

Tamayo EN, Villanueva A, Hasper AA, De Graaff LH, Ramon D, Orejas M. CreA mediates repression of the regulatory gene $x \ln R$ which controls the production of xylanolytic enzymes in Aspergillus nidulans. Fungal Genet Biol. 2008:45:984-93.

Te'o VSJ, Bergquist PL, Nevalainen KMH. Biolistic transformation of Trichoderma reesei using the Bio-Rad seven barrels hepta adaptor system. J Microbiol Methods. 2002;51:393-9.
Teng C, Jia H, Yan Q, Zhou P, Jiang Z. High-level expression of extracellular secretion of a $\beta$-Xylosidase gene from Paecilomyces thermophila in Escherichia coli. Bioresour Technol. 2011;102:1822-30.

Thygesen A, Thomsen AB, Schmidt AS, Jorgensen $H$, Ahring BK, Olsson L. Production of cellulose and hemicellulose-degrading enzymes by filamentous fungi cultivated on wet-oxidised wheat straw. Enzyme Microb Technol. 2003;32:606-15.

Tsujibo H, Takada C, Tsuji A, Kosaka M, Miyamoto K, Inamori Y. Cloning, sequencing, and expression of the gene encoding an intracellular $\beta$-D-xylosidase from Streptomyces thermoviolaceus OPC-520. Biosci Biotechnol Biochem. 2001;65:1824-31.

Umemoto Y, Onishi R, Araki T. Cloning of a novel gene encoding $\beta-1,3-$ xylosidase from a marine bacterium, Vibrio sp. Strain XY-214, and characterization of the gene product. Appl Environ Microbiol. 2008;74:305-8.

Utt EA, Eddy CK, Keshav KF, Ingram LO. Sequencing and expression of the butyrivibrio fibrisolvens $x y l b$ gene encoding a novel bifunctional protein with $\beta$-D-Xylosidase and $\mathrm{a}-\mathrm{L}$-arabinofuranosidase activities. Appl Environ Microbiol. 1991;57:1227-34.

van Peij NNME, Brinkmann J, Vrsanska M, Visser J, de Graaff LH. ß-Xylosidase activity, encoded by $x / n D$, is essential for complete hydrolysis of xylan by Aspergillus niger but not for induction of the xylanolytic enzyme spectrum. Eur J Biochem. 1997;245:164-73.

Voronovsky AY, Rohulya OV, Abbas CA, Sibirny AA. Development of strains of the thermotolerant yeast Hansenula polymorpha capable of alcoholic fermentation of starch and xylan. Metab Eng. 2009;11:234-42.

Wakiyama M, Yoshihara K, Hayashi S, Ohta K. Purification and properties of an extracellular $\beta$-Xylosidase from aspergillus japonicus and sequence analysis of the encoding gene. J Biosci Bioeng. 2008;106:398-404.

Wegener S, Ransom RF, Walton JD. A unique eukaryotic $\beta$-Xylosidase gene from the phytopathogenic fungus Cochliobolus carbonum. Microbiology. 1999;145:1089-95.

Whitehead TR, Hespell RB. The genes for three xylan-degrading activities from Bacteroides ovatus are clustered in a 3.8-kilobase region. J Bacteriol. 1990;172:2408-12.

Xia W, Shi P, Xu X, Qian L, Cui Y, Xia M, Yao B. High level expression of a novel family 3 neutral $\beta$-Xylosidase from humicola insolens $y 1$ with high tolerance to d-xylose. PLoS ONE. 2015;10(2):e0117578. doi:10.1371/journal. pone. 0117578 .

Yang $X$, Shi P, Huang H, Luo H, Wanga Y, Zhang W, Yao B. Two xylose-tolerant $\mathrm{GH} 43$ bifunctional b-xylosidase/a-arabinosidases and one $\mathrm{GH} 11$ xylanase from Humicola insolens and their synergy in the degradation of xylan. Food Chem. 2014;148:381-7.

Zafar M, Ahmed S, Khan MIM, Jamil A. Recombinant expression and characterization of a novel endoglucanase from Bacillus subtilis in Escherichia coli. Mol Biol Rep. 2014:41:3295-302.

Zhong YH, Wang XL, Wang TH, Jiang Q. Agrobacterium-mediated transformation (AMT) of Trichoderma reesei as an efficient tool for random insertional mutagenesis. Appl Microbiol Biotechnol. 2006;73:1348-54.

\section{Submit your manuscript to a SpringerOpen ${ }^{\odot}$ journal and benefit from:}

- Convenient online submission

- Rigorous peer review

- Immediate publication on acceptance

- Open access: articles freely available online

- High visibility within the field

- Retaining the copyright to your article

Submit your next manuscript at springeropen.com 